\title{
Preliminary study on the synthesis and high-resolution NMR analysis of Naproxen and Ibuprofen esters
}

\author{
Christopher K. Jankowski ${ }^{\text {a,* }}$, Gaetan LeClair ${ }^{\text {a }}$, André Aumélas ${ }^{\text {a }}$, \\ Mario Gonzalez-de la Parra ${ }^{\mathrm{b}}$, Manuel Jimenez-Estrada ${ }^{\mathrm{b}}$, Veronica Tejada ${ }^{\mathrm{b}}$, \\ Ricardo Chilpa-Reyes ${ }^{\mathrm{b}}$, Jacqueline M.R. Bélanger ${ }^{\mathrm{c}}$ and J.R. Jocelyn Paré ${ }^{\mathrm{c}}$ \\ ${ }^{a}$ Département de Chimie et Biochimie, Université de Moncton, Moncton, NB E1A 3E9, Canada \\ ${ }^{\mathrm{b}}$ Instituto de Quimica and Departamento de Farmacia, Faculdad de Quimica, UNAM, \\ Cd. Universitaria Circuito Exterior, 04510 Mexico, DF, Mexico \\ ${ }^{\mathrm{c}}$ Microwave-Assisted Process Division, Environment Canada, Ottawa, ON K1A OH3, Canada
}

Dedicated to J.M. Muchowski on his 65th birthday remembering the sabbatical at Syntex SA.

\begin{abstract}
The synthesis and NMR analysis of several diastereoisomeric Naproxyl-Naproxenate, Naproxyl-Ibuprofenate and Ibuprofyl-Naproxenate esters are reported. The NMR high resolution spectra run in presence of the chiral shift reagents and variable temperature analysis were done to study the dynamic properties of these esters.

Keywords: Anti-inflammatory, ester, NSAID, variable temperature NMR spectroscopy, shift reagent NMR and molecular modelling
\end{abstract}

\section{Introduction}

The two popular anti-inflammatory and analgesic compounds Naproxen ((2S) 2-(6-methoxy-2naphtyl) propanoic acid) ((2S)-1) and Ibuprofen ((2S) 2-(4-isobutylphenyl) propanoic acid) ((2S)-2) belong to the non-steroidal anti-inflammatory drug family (NSAID). They are derivatives of propionic acids and are often used as an alternative to salicylates in non-prescription pain relief drugs. The presence of the carboxylic group is responsible for partial gastrointestinal toxicity [1,2]. One possible way to reduce gastrointestinal toxicity is by amidation of the carboxyl, as performed in the case of acetaminophen, but can also be done via different esterifications. This approach opens simple but unusual routes to new drug design. It is worthy to note that Naproxen esters were prepared and tested by our group for different physiological activities (e.g., as germination inhibitors) [3,4].

Shanbhag studied a series of Naproxen and Ibuprofen esters, in particular, for gastrointestinal toxicity [5]. The alcoxy moiety of these esters came from phenyl and ethylamine derivatives. Since hydrolysis will eventually occur and yield the free drug and free alcoxy moiety, testing is essential as foreign substances usually have an effect whether it be positive or negative. In order to reduce such effects,

\footnotetext{
${ }^{*}$ Corresponding author. E-mail: jankowc@umoncton.ca.
} 
<smiles>COc1ccc2cc(CC(=O)O)ccc2c1</smiles>

$(2 S)-1$<smiles>COc1ccc2cc(CCO)ccc2c1</smiles>

(2S)-3<smiles>CC(C)Cc1ccc(C(C)C(=O)O)cc1</smiles>

$(2 S)-2$<smiles>CC(C)Cc1ccc(C(C)CO)cc1</smiles>

$(2 S)-4$<smiles>COc1ccc2cc(C(C)COC(=O)[C@H](C)c3ccc4cc(OC)ccc4c3)ccc2c1</smiles>

Scheme 1. Studied esters (the' notation refers to the alkoxyl moiety of the ester).

our group was interested in preparing and in studying the properties of esters obtained by coupling either acids (2S)-1 or (2S)-2 to their corresponding alcohols, naproxol ((2S) 2-(6-methoxy-2-naphtyl) propan-1-ol) ((2S)-3) and ibuprofenol ((2S) 2-(4-isobutylphenyl) propan-1-ol) ((2S)-4) (Scheme 1). The resulting homo or hetero Naproxen or Ibuprofen esters (e.g., (2'S,2S)-5, (2'S,2S)-6 and (2'S,2S)-7) have several potential applications. First the masking of the carboxylic group via esterification is done with the closely related alcohol, reducing gastrointestinal toxicity. Secondly, the hydrolysis of the ester releases the acid and its corresponding primary alcohol, which can subsequently be oxidized to the acid in presence of the appropriate enzymes. These alcohols could be considered as the direct oxidation precursor of the acid. Their oxidation, although necessary to display the additional NSAID activity from the twin product compared to the administration of the free Naproxen, for instance, is easily foreseeable under normal physiological conditions without compromising digestive tract integrity.

The second important problem which occurs is the fact that both drugs are chiral and the asymmetric carbon configuration for physiological activity must be $\mathrm{S}$. The epimeric compounds have both lesser activity and need to convert to the S epimer in the human body, as it is the case for (2'S)-2, or eventually are toxic as it is for R-Naproxen. The use of racemates, as for (2'S)-2, is done in practice [6-8], however in the case of Naproxen the only enantiopure form worthy of interest is the $\mathrm{S}$ configuration. 
Four diastereoisomers can be synthesized from the esters. Isomer $(2 ' S, 2 S)-5$ is the main synthetic interest. However, the remaining three diastereoisomers $\left(2^{\prime} S, 2 R\right)-5,\left(2^{\prime} R, 2 S\right)-5$ and $\left(2^{\prime} R, 2 R\right)-5$ may be of some interest if we consider their mechanisms of action and perform some molecular modelling of inhibition of prostaglandin synthesis by these compounds, and assess their potential in the design of new drugs. Finally, it is also foreseeable that the epimeric esters are obtained in trace quantity (or more) during the esterifications, especially under $\mathrm{p}-\mathrm{TsOH}$ catalysis.

Having in hand all enantiomeric alcohols, acids and esters we can also study their molecular properties as seen from NMR experiments. Two sets of experiments are of particular interest - the application of chiral shift reagents to identify the epimerisation degree on the ester and the identification of the specific epimer from the differential induced chemical shift. On the other hand, variable temperature experiments will show the molecular motions within two large aryl esters.

The synthesis of both enantiomeric acids and alcohols for both series will also enable to synthesize the mixed esters, those in particular having naproxyl and ibuprofen residues coming either from acyl or alkoxyl part of these compounds. Finally, in a search for new physiological activity within this family of compounds, the esterification of (2S)-1 (or (2S)-2) could be done with more complex alcohols. In our study we have coupled it to the alcohols coming from the important prenylation precursor - isoprene oxide. These esters can be used as precursors in an active transport of nitrogen monoxide (NO) [9-12].

In this paper we report on the synthesis and the NMR properties of these hindered esters by p-toluenesulfonic acid (p-TsOH) catalysis and on the use of the Micro-wave Assisted Processes $\left(\mathrm{MAP}^{\mathrm{TM}}\right)$, family of technologies [13-16].

\section{Results and discussion}

\subsection{Variable temperature experiments}

Variable temperature experiments were performed on (2'S,2S)-5, (2'S,2S)-6 and (2'S,2S)-7 esters. In particular the homo esters, having identical substitution on both sides of the ester group, are showing specific behaviors. The fact that two identically substituted aromatic rings present such different spectra indicates that their average magnetic environment is different. Protons of the aromatic alcohol moiety are under the influence of the same environment, however, from NMR spectra, those of the acyl part of the ester are seeing a different environment, essentially due to varying axial rotations speeds.

The esters in this family are represented by a two-axis system (A and B) with two different rotations around these axes displaying different velocities dependent on ambient temperature (Fig. 1). Several cases of similar phenomena and different speed of internal rotation behavior are described in the literature and reported as rotors [17]. For these ester systems, the following should be verified: is this behavior coming from the epimerisation of $\alpha$-to carbonyl carbon during the experiments, or is it due to the chirality (configuration) on both side of the ester bond that influences these rotations, and finally, what is the temperature effect on diastereoisomers as shown from the proton NMR spectra.

In order to modify this environment, we have recorded a series of spectra of ester $(2 S, 2 S)$-5 at temperatures varying from 7 to $50^{\circ} \mathrm{C}$ (Fig. 2). Increasing the temperature to $50^{\circ} \mathrm{C}$ induced small modification in the spectra such as increased proton non-equivalency of the aromatic signals from the acyl side while the aromatic protons from the alkoxyl side of the ester were perfectly equivalent.

The diastereotopic methylene protons gave rise to isochronous signals at $7^{\circ} \mathrm{C}$ (a doublet at $\delta 4.2$ ), whereas at $50^{\circ} \mathrm{C}$ their environment was altered and their resonances were both downfield shifted and 


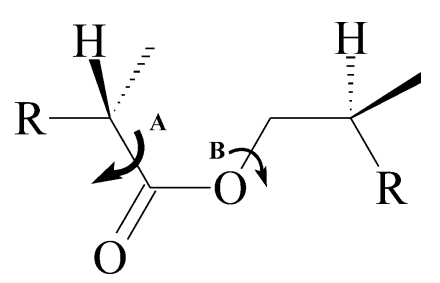

Fig. 1. Ester mobility.
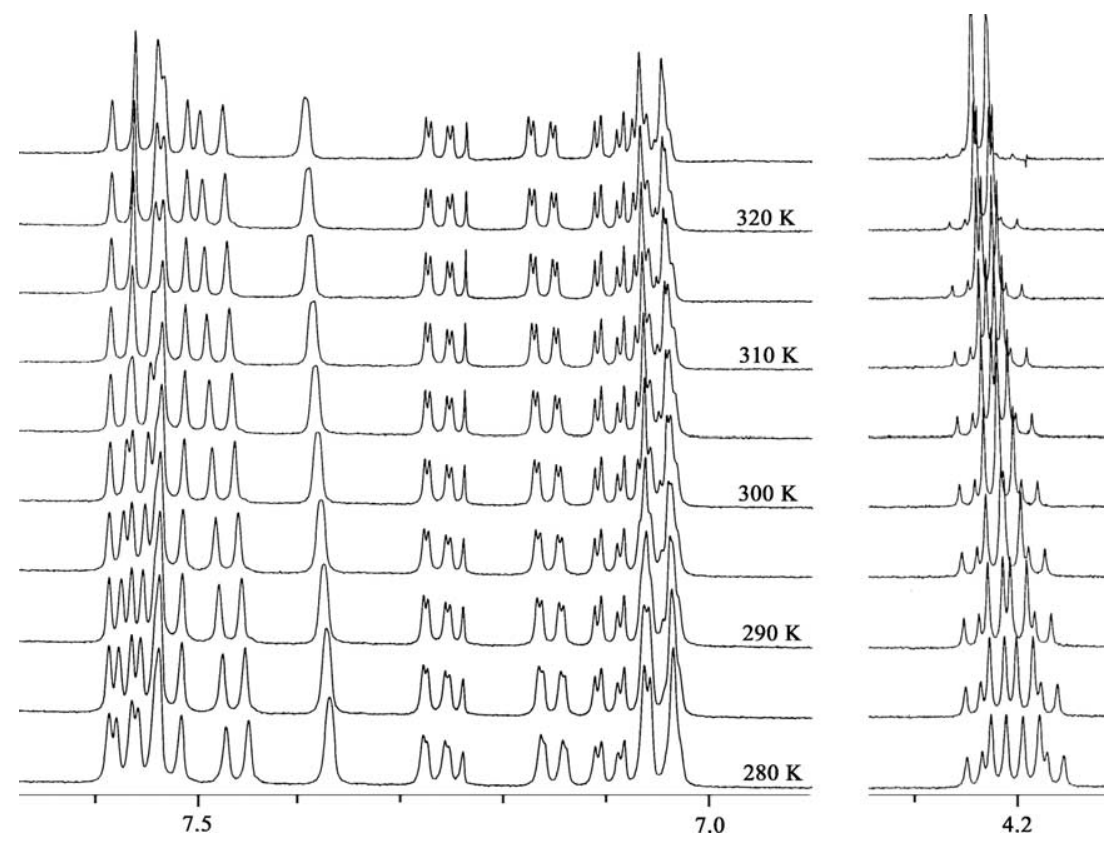

Fig. 2. Variable temperature NMR spectra of ester (2'S,2S)-5.

slightly separated (doublet of doublets of doublets). While peak height suggests doublet of doublets of quartet (ddq), at $200 \mathrm{MHz}$, there is some overlap and the resulting signal resembles ddq.

These differences in behavior with temperature variation mean that the differences in ring dynamics of two aromatic cycles of the molecule resulted from the different mobility around the internal rotation axis (Fig. 1). The aromatic protons equivalence from the alkoxyll side can be interpreted as the axial rotation around $\mathrm{O}-\mathrm{CH}_{2}$ and $\mathrm{CH}_{2}-\mathrm{CH}\left(\mathrm{CH}_{3}\right)$ bonds. This behavior was observed for several diasteroisomeric esters despite the lesser optical purity of some diasteroisomers.

The simplest models for this series without the asymmetric center are the (2-phenyl propyl) 2-phenyl propionates $\mathbf{8}$ and $\mathbf{9}$ (Scheme 2). Both were synthesized by acid chloride methodology with the appropriate acid chloride and alcohol. While phenyl does not possess the same rotational properties as naphtyl, these esters also display the same rotamer property as those with asymmetric esters. We concluded that this behavior is independent on the configuration of asymmetric centers.

The conformation of the homo esters gives rise to a non-equivalence of the aromatic rings and also to that of the protons from the methylene signal $\left(\mathrm{O}-\mathrm{CH}_{2}\right)$. We used molecular modelling to assess the conformation of the esters. The starting geometry was that of both bulky residues opposite to each other to minimize their repulsion. For ester $\left(2^{\prime} S, 2 S\right)-5$, the resulting optimized conformation was not linear 
<smiles>O=C(Cc1ccccc1)OCc1ccccc1</smiles>

8<smiles>O=C(Cc1ccccc1)OCCc1ccccc1</smiles>

9

Scheme 2. Model esters.

as expected but surprisingly, the naphtyl groups were perpendicular to each other. Further modification of this conformation by rotating one naphtyl until both were parallel (both in the same plane) and then optimizing the geometry, led to the determination of the privileged conformation of these esters as being folded in a syn conformation (see Fig. 9).

The administration of multiple drugs is not usually recommended, but (2S)-1 and (2S)-2 are compatible with each other. In order to complete the whole picture, Nap-Ibu and Ibu-Nap esters were considered. Having achieved the reduction of $(2 S)-2$ to $(2 S)-4$ from a fresh $\mathrm{BH}_{3}$-etherate solution, we immediately tried to form ester (2'S,2S)-6. To compensate for poor water elimination from the reaction medium, we filled the Dean-Stark tube with anhydrous toluene thus completing the reflux system from the start. The yield was almost quantitative. Interestingly, from the NMR spectra, methylene protons were isochronous. Therefore, structure mobility is more pronounced at room temperature than for Naproxen homo esters. Further proof of this lies within the aromatic protons of ibuprofen moiety. The aromatic protons of (2S)-3 are composed of two sets of well resolved doublets of doublets (vicinal and long range coupling constants), but the corresponding protons of $(2 ' S, 2 S)-6$, while still displaying 8 peaks, shows significant overlap. Since the Ibuprofen moiety is smaller than the Naproxen moiety, it is understandable that it will have a greater velocity as confirmed by NMR averaged signals. Variable temperature experiments done on (2'S,2S)-6 (Fig. 3) showed a pattern similar to that of Naproxen homo esters. Non-equivalence of the methylene protons is observed at low temperatures but at higher temperatures (room temperature and above), the methylene protons become isochronous which confirms velocity observations.

\subsection{Chiral shift reagents experiments}

The diastereoisomeric Naproxen homo esters were examined with the help of a NMR chiral shift reagent $\left(\mathrm{SR}^{*}\right)$. Since enantiomers would yield the same information, we only examined one pair of enantiomer ((2'S,2S)-5 and (2'R,2R)-5) and one diastereoisomer ((2'R,2S)-5). This enabled us to evaluate the racemisation, enantiopurity levels, as well as verify the proton signals assignments. The esters, formed complexes with europium via the carbonyl (CO) or carboxyl groups (COO) (we are uncertain which site has a higher affinity for the $\mathrm{SR}^{*}$ ), but definitely not with both methoxy groups, as the induced chemical shift was almost non-existent. Assuming that the equimolar complex (lanthanide/substrate) is the only species present at low ratio of shift reagent/compound in $\mathrm{CDCl}_{3}$ solution, one can relate the geometry of the proton toward lanthanide on the complexation site of ester to the induced shift. Usually, the epimeric protons, being in the vicinity of the complexation center will display such a differential SR* induced chemical shift which can be related to the configuration. The optically active shift reagent can display important differences in induced chemical shifts if reagent and substrate are of the same absolute configuration (e.g., R-shift reagent for protons of R-epimer). The quasi-racemate formation between the $\mathrm{R}$-shift reagent and S-proton explains smaller induced chemical shift observed for this optical isomer. 

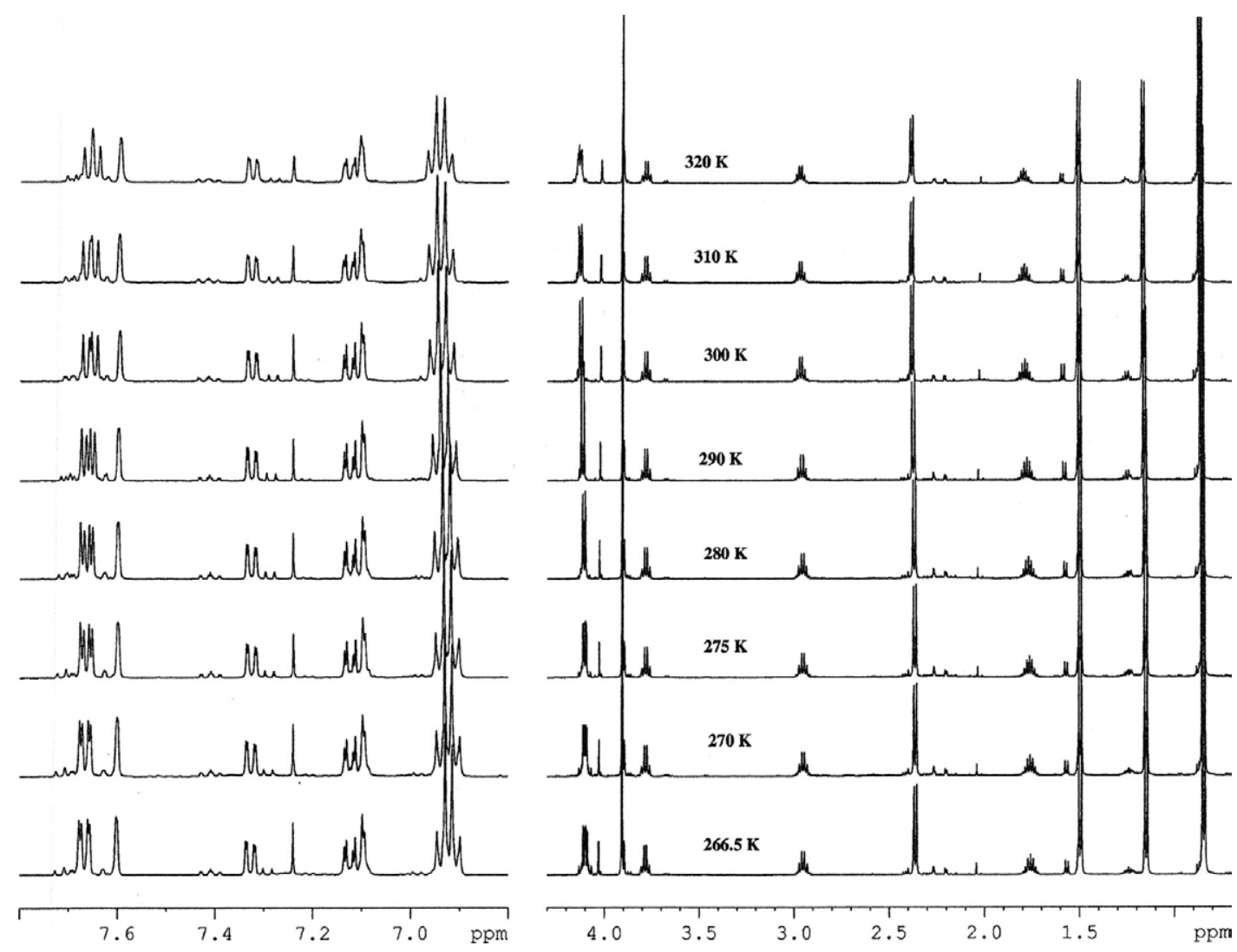

Fig. 3. Variable temperature NMR spectra of ester (2'S,2S)-6.

The spectra of the esters were recorded in the presence of europium shift reagents (e.g., $\left.\mathrm{Eu}(\mathrm{hfc})_{3}\right)$ at concentrations not exceeding a 1:1 ratio. The induced chemical shift for propionate signals at various molar ratios (up to $\approx 1$ ) are shown in Figs 4, 5 and 6.

The europium $\mathrm{SR}^{*}$ is shifting more the signals of $\mathrm{CH}$ then $\mathrm{CH}_{3}$. The chemical induced shift pseudocontact component is expressed, according to the improved McConnell-Robertson equation, as a sum of axial and nonaxial geometrical terms where the shift depends on the angle $\theta$ formed between the metal, complexed group donor and the proton. In the case of enantiomers the $\cos ^{2} \theta$ term is the same for the angle $+\theta$ and $-\theta$ however the $R^{3}$ distance and other trigonometric functions will vary with the geometry of the esters.

The $\mathrm{CH}_{2}$ signals can be used to follow the progress of racemization since a racemic mixture will have an overlap of the 2 signals (Fig. 7). During the SR* experiments, we also noted that the methylene signal (Fig. 4) of the Naproxen esters splits into two signals (Fig. 8) suggesting a certain rigidity.

These esters, being able to rotate freely, should not display such rigidity. The attraction between the two naphtyl groups, found by molecular modelling and similar to the interactions found in graphite (Fig. 9), acts as the source of rigidity therefore creating a non-equivalence between the diastereotopic protons of the methylene group (at room temperature or lower). Similar behavior for all other Naproxen homo esters was observed.

The slopes, obtained by linear regression from the plot of the data of Figs 4, 5 and 6 show that the most pronounced separation of signals is at the carbonyl side of the ester. Also, the methyne protons have a 


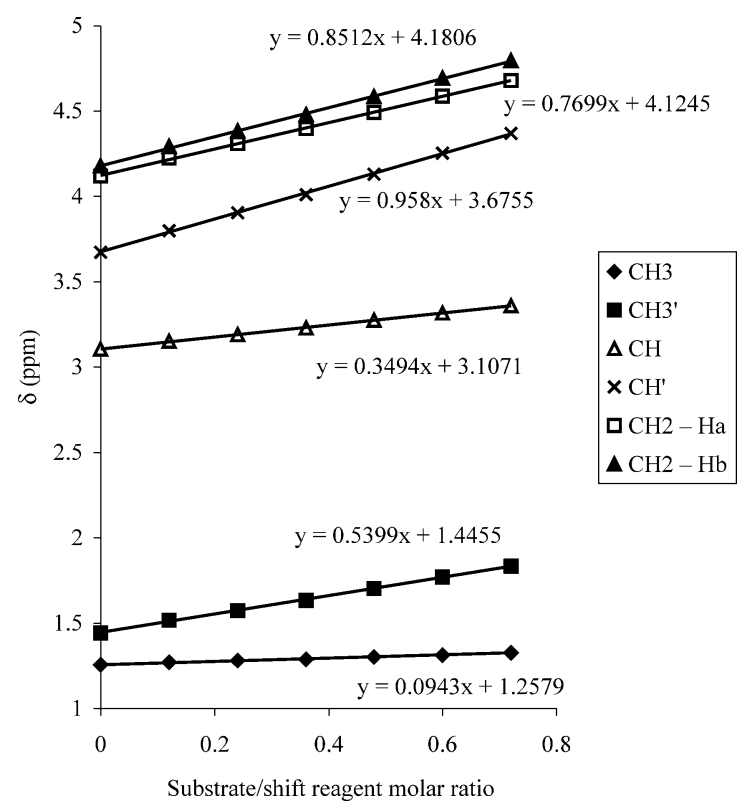

Fig. 4. Induced chemical shift for ester (2'S,2S)-5.

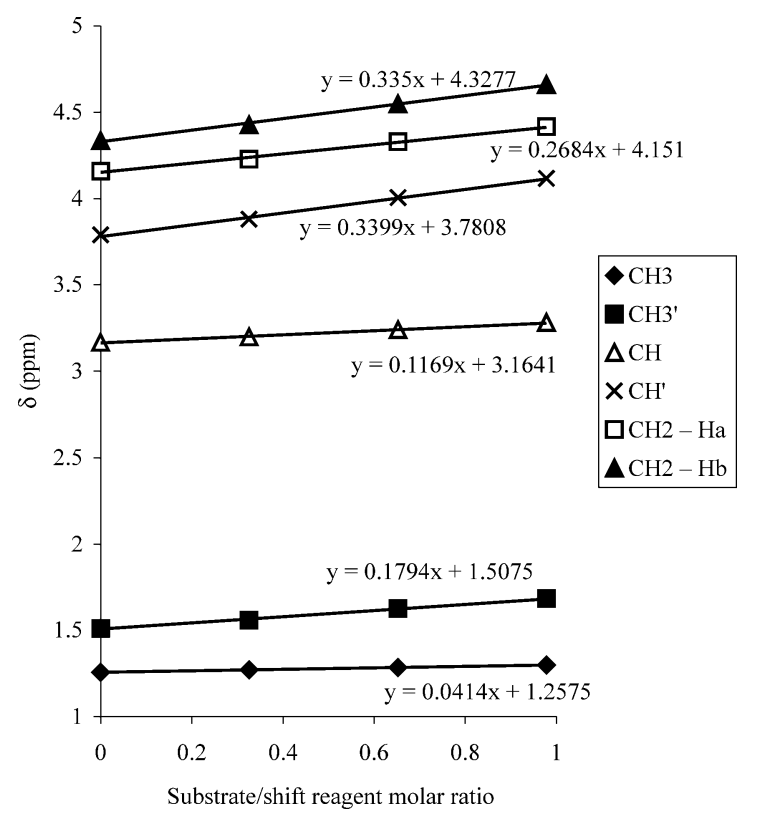

Fig. 5. Induced chemical shift for ester (2'R,2S)-5.

more pronounced shift than the methyl protons. This observation means that the complexation site is not symmetric but lies closest to the carbonyl group of the ester. Two cation complexation orientations were considered, one situated along the axis of the $\mathrm{C}=\mathrm{O}$ bond (at approximately $2.5 \AA$ ) and the second, with both oxygens of the ester on the less hindered face of the plane defined by the ester group (with the lanthanide centered between the oxygens). In either case, the lanthanide is closer to the carbonyl 


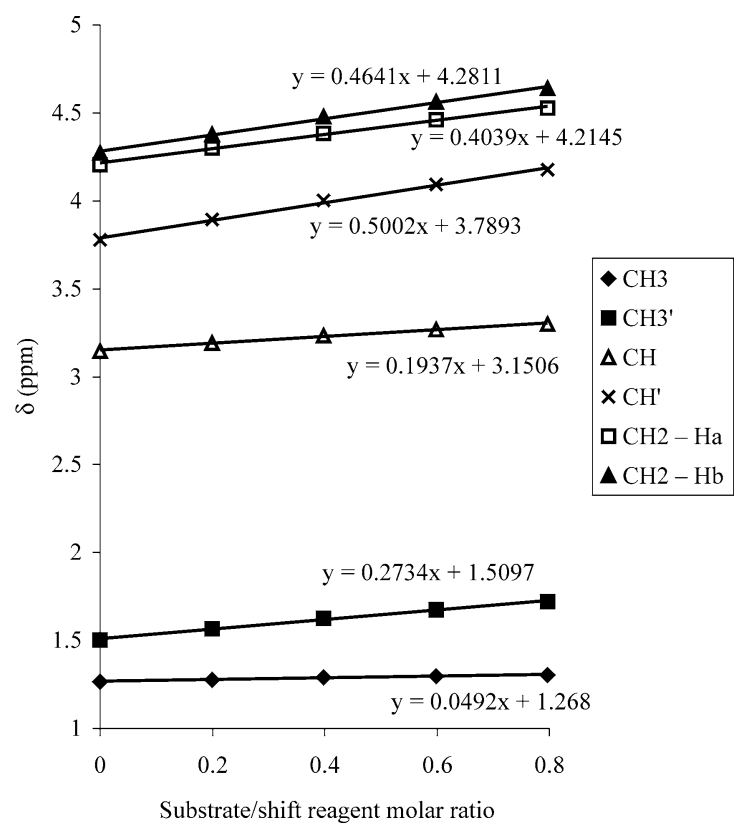

Fig. 6. Induced chemical shift for ester (2'R,2R)-5.

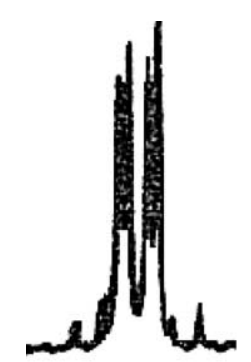

a)

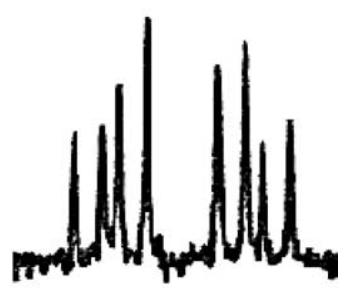

b)

Fig. 7. Methylene protons of esters (2'S,2S)-5 and (2'R,2S)-5 in a and b, respectively.

part of the ester and will induce a more pronounced shift of the protons at the carbonyl side. When considering molecular modeling to determine the nature of the complexation site, four possible scenarios arise (Fig. 10). A simple alignment of the europium complex along the desired position has proved futile as Hyperchem simulates in vacuum and therefore the only interactions are those of the free molecules which were moved apart as to minimize repulsions.

The calculated S/R pseudocontact shift ratios (Table 1) from a modified McConnell-Robinson equation (experimental section), should be higher than $1(\mathrm{~S} / \mathrm{R}>1)$ to be in accordance with experimental observations. Distances and angles, obtained from these simulations, have lead to ratios that are higher than 1 for some signals but not for all. To concur with experimental results every calculated shift has to be higher than 1. If this condition is not fulfilled, these models are not valid. To prevent the molecules to be separated too far to minimize repulsion, two new models were created with the europium coordinated to the respective complexation site. Again, from pseudo-contact shift calculations (Table 1), the O-Eu-O and $\mathrm{Eu}-\mathrm{O}=\mathrm{C}$ models are not in accordance with experimental observations. The set of ratios that were 


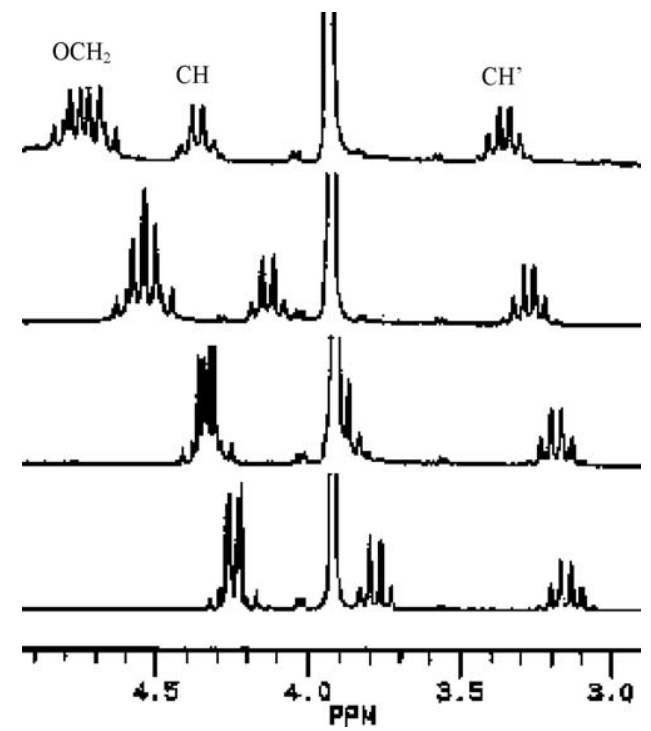

Fig. 8. SR* induced shift of ester (2'S,2S)-5 at 0, 0.06 (lower), 0.12 (median) and 0.18 (upper run) molar ratios.

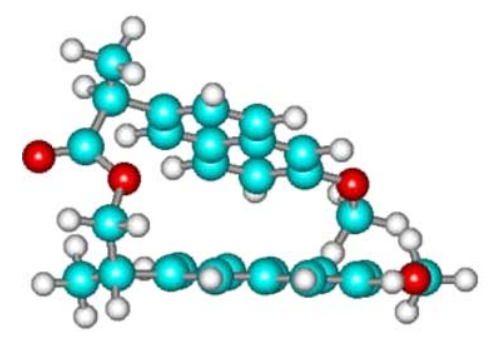

side view

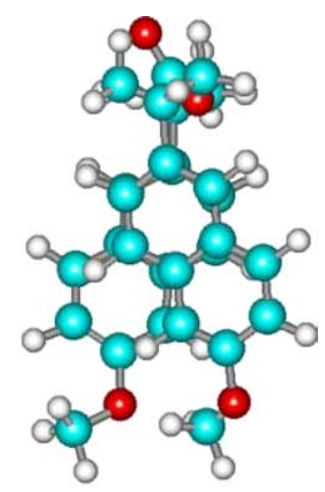

top view

Fig. 9. Stacking of ester (2'S,2S)-5.

closest to experimental observations was for model iii since for 3 of the calculated shifts, while under 1 , were close to 1 and the fourth being higher than 1. Further modifications of iii might lead to a better approximation.

\subsection{Prenylation of propionates - linkers to NO generating molecules}

From two commercially available alcohols, racemic isoprene-2-methyl-3-buten-1-ol (10) and isomeric 2-methyl-3-buten-2-ol (11), only 10 gave a satisfactory yield of unsaturated ester $( \pm, 2 S)$-12 following esterification with (2S)-1 (Scheme 3). 

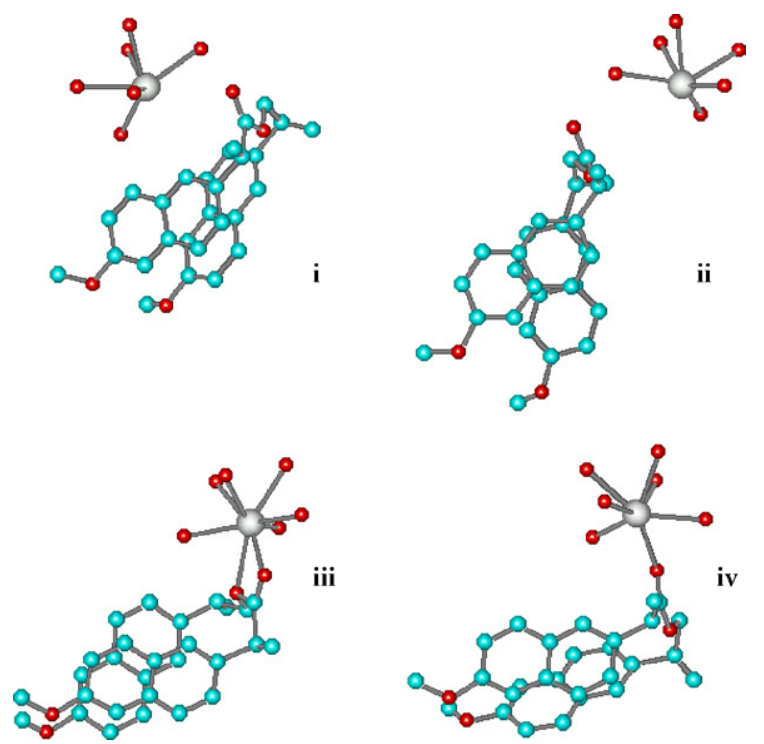

Fig. 10. Proposed chelation sites.<smiles>C=C[C@H](C)COC(=O)[C@H](C)c1ccc2cc(OC)ccc2c1</smiles>

Scheme 3. Linker precursor.

\section{Conclusion}

The preparation of esters was achieved for several attempted goal products. However, the esterification of highly hindered acids, by equally cumbersome alcohols do represent a major difficulty. Due to poor water elimination during reflux, some of the yields were low. In the case of ester $(2, R, 2 S)-6$, filling the Dean-Stark tube with anhydrous toluene prior to reflux gave excellent yield. The use of microwaveassisted esterification instead of $\mathrm{p}-\mathrm{TsOH}$ catalysis or acid catalysis did not improve the yield of homo or linker type ester. Linker type ester $( \pm, 2 S)-12$, was however isolated in moderate yield.

The ibuprofen esters in general are more difficult to isolate. The starting alcohol for the synthesis of ester was obtained in poor yield. Since we recently obtained alcohol (2S)-4 in quantitative yield, we will attempt synthesizing the Ibuprofen homo esters again.

Because of small energy differences between chosen minimized structures, it was not possible to pinpoint the exact chelation site of the $\mathrm{SR}^{*}$ with Naproxen esters by molecular modeling. We did however, determine the geometry of the ester as being stacked with the resulting attraction hindering free rotation 
Table 1

Calculated S/R induced shift ratios for esters $\mathbf{5}$ and $\mathbf{8}$

\begin{tabular}{|c|c|c|c|c|c|c|c|c|}
\hline & $\begin{array}{c}\text { Chelation } \\
\text { site }\end{array}$ & $\mathrm{C}^{*}$ & $\begin{array}{c}\text { Angle } \theta^{\mathrm{a}} \\
\left({ }^{\circ}\right)\end{array}$ & $\begin{array}{c}\text { Distance } \\
(\AA)\end{array}$ & $\begin{array}{c}\cos \theta \\
\text { (radians) }\end{array}$ & $3 \cos ^{2} \theta-1$ & $R_{i}^{3}$ & $\mathrm{~S} / \mathrm{R}$ \\
\hline \multirow[t]{2}{*}{$\overline{\mathrm{CH}}$} & i & $\mathrm{S}$ & 23.89 & 6.92 & 0.914 & 1.508 & 331.374 & 0.803 \\
\hline & & $\mathrm{R}$ & 24.28 & 6.41 & 0.912 & 1.493 & 263.375 & \\
\hline \multirow[t]{2}{*}{$\mathrm{CH}$} & ii & $\mathrm{S}$ & 41.31 & 4.40 & 0.751 & 0.693 & 85.184 & 1.036 \\
\hline & & $\mathrm{R}$ & 47.56 & 3.60 & 0.675 & 0.366 & 46.656 & \\
\hline \multirow[t]{2}{*}{$\mathrm{CH}$} & iii & $S$ & 13.99 & 4.90 & 0.970 & 1.825 & 117.649 & 0.990 \\
\hline & & $\mathrm{R}$ & 14.15 & 4.88 & 0.970 & 1.821 & 116.214 & \\
\hline \multirow[t]{2}{*}{$\mathrm{CH}$} & iv & S & 37.10 & 4.81 & 0.798 & 0.908 & 111.285 & -2.027 \\
\hline & & $\mathrm{R}$ & 56.86 & 2.95 & 0.547 & -0.103 & 25.672 & \\
\hline \multirow[t]{2}{*}{$\mathrm{CH}_{3}$} & $\mathrm{i}$ & $S$ & 23.47 & 6.18 & 0.917 & 1.524 & 236.029 & 0.665 \\
\hline & & $\mathrm{R}$ & 30.80 & 5.00 & 0.859 & 1.213 & 125.000 & \\
\hline \multirow[t]{2}{*}{$\mathrm{CH}_{3}$} & ii & S & 36.23 & 3.35 & 0.807 & 0.952 & 37.595 & 1.999 \\
\hline & & $\mathrm{R}$ & 37.16 & 4.15 & 0.797 & 0.905 & 71.473 & \\
\hline \multirow[t]{2}{*}{$\mathrm{CH}_{3}$} & iii & $\mathrm{S}$ & 21.36 & 4.98 & 0.931 & 1.602 & 123.506 & 0.994 \\
\hline & & $\mathrm{R}$ & 20.83 & 4.99 & 0.935 & 1.621 & 124.251 & \\
\hline \multirow[t]{2}{*}{$\mathrm{CH}_{3}$} & iv & $\mathrm{S}$ & 65.61 & 2.85 & 0.413 & -0.488 & 23.149 & -8.258 \\
\hline & & $\mathrm{R}$ & 51.67 & 3.92 & 0.620 & 0.154 & 60.236 & \\
\hline \multirow[t]{2}{*}{$\mathrm{CH}^{\prime}$} & $\mathrm{i}$ & $\mathrm{S}$ & 59.23 & 4.80 & 0.512 & -0.215 & 110.592 & 2.111 \\
\hline & & $\mathrm{R}$ & 57.80 & 5.44 & 0.533 & -0.148 & 160.989 & \\
\hline \multirow[t]{2}{*}{$\mathrm{CH}^{\prime}$} & ii & $S$ & 29.81 & 8.10 & 0.868 & 1.259 & 531.441 & -0.809 \\
\hline & & $\mathrm{R}$ & 66.19 & 5.59 & 0.404 & -0.511 & 174.677 & \\
\hline \multirow[t]{2}{*}{$\mathrm{CH}^{\prime}$} & iii & $\mathrm{S}$ & 77.15 & 3.22 & 0.222 & -0.852 & 33.386 & 0.878 \\
\hline & & $\mathrm{R}$ & 79.91 & 3.15 & 0.175 & -0.908 & 31.256 & \\
\hline \multirow[t]{2}{*}{$\mathrm{CH}^{\prime}$} & iv & $\mathrm{S}$ & 14.80 & 7.03 & 0.967 & 1.804 & 347.429 & 0.925 \\
\hline & & $\mathrm{R}$ & 6.04 & 7.05 & 0.994 & 1.967 & 350.403 & \\
\hline \multirow[t]{2}{*}{$\mathrm{CH}_{3}^{\prime}$} & $\mathrm{i}$ & $\mathrm{S}$ & 48.37 & 6.59 & 0.664 & 0.324 & 286.191 & 0.493 \\
\hline & & $\mathrm{R}$ & 40.26 & 6.88 & 0.763 & 0.747 & 325.661 & \\
\hline \multirow[t]{2}{*}{$\mathrm{CH}_{3}^{\prime}$} & ii & $\mathrm{S}$ & 44.17 & 6.45 & 0.717 & 0.543 & 268.336 & -0.227 \\
\hline & & $\mathrm{R}$ & 62.80 & 3.47 & 0.457 & -0.373 & 41.782 & \\
\hline \multirow[t]{2}{*}{$\mathrm{CH}_{3}^{\prime}$} & iii & $S$ & 77.40 & 4.46 & 0.218 & -0.857 & 88.717 & 1.308 \\
\hline & & $\mathrm{R}$ & 73.99 & 4.71 & 0.276 & -0.772 & 104.487 & \\
\hline \multirow[t]{2}{*}{$\mathrm{CH}_{3}^{\prime}$} & iv & $S$ & 8.47 & 7.04 & 0.989 & 1.935 & 348.914 & 1.159 \\
\hline & & $\mathrm{R}$ & 17.32 & 7.13 & 0.955 & 1.734 & 362.467 & \\
\hline
\end{tabular}

${ }^{\mathrm{a}}$ Angles for sites i, ii and iv are $\mathrm{O}-\mathrm{Eu}-\mathrm{H}$ while angles for site iii are $\mathrm{C}-\mathrm{Eu}-\mathrm{H}$ as both oxygens are implicated in the complexation (Fig. 10).

(even at moderate temperatures). While Hyperchem is a useful modeling tool, it does have limitations while trying to further mimic complex structures.

Preliminary physiological testing of ester $(2 ' S, 2 S)-5$ was done and shows low gastrointestinal toxicity. More specific physiological testing will follow. 


\section{Experimental}

Naproxen, Ibuprofen, all isomers, and other products and reagents were purchased from Aldrich Chemicals. The uncommon $\mathrm{R}$ isomer was synthesized according to Gonzales-de la Parra method [3]. The corresponding alcohols were obtained by $\mathrm{BH}_{3}$ reduction of respective acid. Racemic Naproxen was obtained from the $\mathrm{S}$-isomer by sodium hydroxide induced racemisation followed by polarimetric control of the ethanol $10 \%$ solution. The ${ }^{1} \mathrm{H}-\mathrm{NMR}$ spectra were recorded on a Bruker $200 \mathrm{MHz}, 300 \mathrm{MHz}$ or $400 \mathrm{MHz}$ spectrometer. Variable temperature spectra were recorded on a Bruker 500 or $600 \mathrm{MHz}$ spectrometer ${ }^{13} \mathrm{C}$-NMR spectra were recorded at 50 and $75 \mathrm{MHz}$. The samples were dissolved in $\mathrm{CDCl}_{3}$ and its residual signal at $7.24 \mathrm{ppm}$ or TMS was used as an internal standard. The typical NMR procedure is described in a previous paper [15].

The complete set of NMR experiments spectra in 1D and 2D for compounds 1-16 are available on request. The positive ion (PI) mass spectra were determined on Riber 1010 and 3010 apparatus in EI $(70 \mathrm{eV})$ or CI (methane gas from Alpha gas Co.) modes using EI-CI source.

\section{Reduction of (2S)-1 and (2S)-2 (Harrison procedure [17]) to alcohols}

Acids (2S)-1 or (2S)-2 $(48.8 \mathrm{mmol})$ and THF $(24 \mathrm{ml})$ were placed in a $250 \mathrm{ml}$ round bottom flask and cooled to $0-5^{\circ} \mathrm{C}$ with an ice bath for $30 \mathrm{~min}$. After dropwise addition of a $\mathrm{BH}_{3} \cdot \mathrm{THF}$ solution $(1 \mathrm{M}$, $57 \mathrm{ml}$ ), the mixture was stirred for $30 \mathrm{~min}$ and extracted with aqueous $\mathrm{HCl}$ solution $(1 \%, 25 \mathrm{ml})$. After evaporation of the solvents, alcohols (2S)-3 and (2S)-4 were obtained as a white powder $\left(\mathrm{mp} 87^{\circ} \mathrm{C}\right)$ and a colorless viscous liquid respectively, with respective yields of $87 \%$ and $86 \%$.

\section{Acid catalyzed esterification: general method}

Acid (1.1 mmol), alcohol (1.0 mmol), p-TsOH (40 mg) and anhydrous toluene $(15 \mathrm{ml})$ were placed in a $100 \mathrm{ml}$ round bottom flask. The resulting mixture was stirred and heated to reflux under a Dean-Stark condensation system ${ }^{1}$ for $5 \mathrm{~h}$. Following solvent evaporation, the product was purified on $20 \times 20 \mathrm{~cm}$ TLC plates $(0.5 \mathrm{~mm}$ silica gel $\mathrm{G})$ using chloroform as eluent or by silica gel flash chromatography (63 mesh) using ethyl acetate/petroleum ether (30:70) as the eluent. Each ester was obtained as a white powder except for esters $\left(2^{\prime} S, 2 S\right)-6,\left(2^{\prime} S, 2 S\right)-7$ and $( \pm, 2 S)-12$, which were yellow viscous liquids. Yields were $64 \%$ for ester $\left(2^{\prime} S, 2 S\right)-5\left(\mathrm{mp} 118^{\circ} \mathrm{C}\right), 64 \%$ for ester $\left(2^{\prime} \boldsymbol{R}, 2 S\right)-5\left(\mathrm{mp} 113^{\circ} \mathrm{C}\right), 72 \%$ for ester $\left(2^{\prime} S, 2 R\right)-57\left(\mathrm{mp} 113^{\circ} \mathrm{C}\right), 73 \%$ for ester $\left(2^{\prime} \boldsymbol{R}, 2 \boldsymbol{R}\right)-5\left(\mathrm{mp} 118^{\circ} \mathrm{C}\right), 99 \%$ for ester $\left(\mathbf{2}^{\prime} \mathbf{S}, 2 \mathrm{~S}\right)-\mathbf{6}, 67 \%$ for ester $(2 ' S, 2 S)-7$ and $63 \%$ for ester $( \pm, 2 S)-12$.

\section{$M A P^{T M} 2$ esterification of (2'S,2S)-5}

Acid (2S)-1 (1.3 mmol), alcohol (2S)-3 (1.24 mmol), p-TsOH (30 mg), Teflon boiling chips and anhydrous toluene $(50 \mathrm{ml})$ were placed in a pyrex tube. The equipment is a Star- 6 open vessel microwave unit (CEM Corp.). The solution was irradiated for $20 \mathrm{~min}$ at a maximum power of $240 \mathrm{~W}$ (20\% of full power) with a set temperature of $128^{\circ} \mathrm{C}$ (max temperature). Yield, calculated from NMR proton spectra of ester (2'S,2S)-5, was $23.5 \%$.

\section{Shift reagent experiments [18-21]}

Tris[(heptafluoropropylhydroxy methylene-3 (+)-camphorate] europium was used as the shift reagent $\left(\mathrm{SR}^{*}\right)$. The stock solution of approximately $2 \mathrm{mg}$ of ester in $0.5 \mathrm{ml}$ of $\mathrm{CDCl}_{3}$ was prepared. To this solution, $10 \mu \mathrm{l}$ of $\mathrm{SR}^{*}$ portions ( $50 \mathrm{mg}$ in $1 \mathrm{ml}$ of $\mathrm{CDCl}_{3}$ ) were added to the NMR tube and left spinning

\footnotetext{
${ }^{1}$ Dean-Stark tube was filled with anhydrous toluene before reflux.

${ }^{2}$ MAPtex ${ }^{\text {TM }}$ is a trademark of Her Majesty the Queen in Right of Canada as represented by the Minister of the Environment.
} 
in the magnet for $30 \mathrm{~min}$ (equilibrium time) before acquisition. This step was repeated until the molar ratio of $\mathrm{SR}^{*}$ to product approached 1 .

S/R pseudocontact shift ratio were calculated using the following equation:

$$
\frac{(\delta / \nu)_{S}}{(\delta / \nu)_{R}} \cong \frac{\left[\left(3 \cos ^{2} \theta_{S}-1\right) / R_{S}^{3}\right]}{\left[\left(3 \cos ^{2} \theta_{R}-1\right) / R_{R}^{3}\right]} \cong \frac{R_{R}^{3}}{R_{S}^{3}}\left(\frac{3 \cos ^{2} \theta_{S}-1}{3 \cos ^{2} \theta_{R}-1}\right)
$$

Molecular modeling

Molecular modeling simulations were done in vacuo using MM+ forcefield with HyperChem 6.02 [22]. Simulations converged when energy gradient was inferior to 0.005 .

\section{NMR data}

\section{1. (2S)-2-(6-methoxy-2-naphtyl) propanoic acid ((2S)-1)}

${ }^{1} \mathrm{H}-\mathrm{NMR}\left(200 \mathrm{MHz}, \mathrm{CDCl}_{3}\right): \delta 1.57\left(\mathrm{~d},{ }^{3} \mathrm{~J}_{\mathrm{CHCH}_{3}}=7 \mathrm{~Hz}, \mathrm{CHCH}_{3}\right), 3.85\left(\mathrm{q},{ }^{3} \mathrm{~J}_{\mathrm{CHCH}_{3}}=7 \mathrm{~Hz}, \mathrm{CHCH}_{3}\right)$, $3.89\left(\mathrm{~s}, \mathrm{OCH}_{3}\right), 7.09\left(\mathrm{~d},{ }^{4} \mathrm{~J}_{5,7}=-2 \mathrm{~Hz}, 5-\mathrm{H}\right) ; 7.12\left(\mathrm{dd},{ }^{3} \mathrm{~J}_{7,8}=8 \mathrm{~Hz},{ }^{4} \mathrm{~J}_{5,7}=-2 \mathrm{~Hz}, 7-\mathrm{H}\right), 7.39(\mathrm{dd}$, $\left.{ }^{3} \mathrm{~J}_{3,4}=8 \mathrm{~Hz},{ }^{4} \mathrm{~J}_{1,3}=-2 \mathrm{~Hz}, 3-\mathrm{H}\right), 7.67\left(\mathrm{~d},{ }^{4} \mathrm{~J}_{1,3}=-2 \mathrm{~Hz}, 1-\mathrm{H}\right), 7.68\left(\mathrm{~d},{ }^{3} \mathrm{~J}_{3.4}=8 \mathrm{~Hz}, 4-\mathrm{H}\right), 7.69(\mathrm{~d}$, $\left.{ }^{3} \mathrm{~J}_{7,8}=8 \mathrm{~Hz}, 8-\mathrm{H}\right), 10.6(\mathrm{~s}, \mathrm{COOH})$;

${ }^{13} \mathrm{C}-\mathrm{NMR}\left(50 \mathrm{MHz}, \mathrm{CDCl}_{3}\right): \delta 18.14\left(\mathrm{CHCH}_{3}\right), 45.30\left(\mathrm{CHCH}_{3}\right), 55.31\left(\mathrm{OCH}_{3}\right), 105.67(5-\mathrm{C}), 119.04$ (7-C), 126.16 (1-C), 126.21 (3-C), 127.25 (4-C), 128.93 (8a-C), 129.32 (8-C), 133.85 (4a-C), 134.90 (2C); 157.75 (6-C), 180.77 (CO).

\section{2. (2S)-2-(4-isobutylphenyl) propanoic acid ((2S)-2)}

${ }^{1} \mathrm{H}-\mathrm{NMR}\left(200 \mathrm{MHz}, \mathrm{CDCl}_{3}\right): \delta 0.90\left(\mathrm{~d},{ }^{3} \mathrm{~J}_{\mathrm{CH}_{(}\left(\mathrm{CH}_{3}\right)_{2}}=7 \mathrm{~Hz}, \mathrm{CH}_{2} \mathrm{CH}\left(\mathrm{CH}_{3}\right)_{2}\right), 1.50\left(\mathrm{~d},{ }^{3} \mathrm{~J}_{\mathrm{CHCH}_{3}}=\right.$ $8 \mathrm{~Hz}, \mathrm{CHC} \underline{\mathrm{H}} 3), 1.84\left(\mathrm{~m},{ }^{3} \mathrm{~J}_{\left.\mathrm{CH}_{(\mathrm{CH}}\right)_{2}}={ }^{3} \mathrm{~J}_{\mathrm{CHCH}_{2}}=7 \mathrm{~Hz}, \mathrm{CH}_{2} \mathrm{C} \underline{\mathrm{H}}\left(\mathrm{CH}_{3}\right)_{2}\right), 2.44\left(\mathrm{~d},{ }^{3} \mathrm{~J}_{\mathrm{CHCH}_{2}}=7 \mathrm{~Hz}\right.$, $\left.\mathrm{C}_{2} \mathrm{CH}\left(\mathrm{CH}_{3}\right)_{2}\right), 3.70\left(\mathrm{q},{ }^{3} \mathrm{~J}_{\mathrm{CHCH}_{3}}=8 \mathrm{~Hz}, \mathrm{CHCH}_{3}\right), 7.09\left(\mathrm{dd},{ }^{3} \mathrm{~J}_{3,2}=8 \mathrm{~Hz},{ }^{4} \mathrm{~J}_{\mathrm{H} 3, \mathrm{H} 3},=-2 \mathrm{~Hz}, 3-\mathrm{H}\right)$; $7.22\left(\mathrm{dd},{ }^{3} \mathrm{~J}_{3,2}=8 \mathrm{~Hz},{ }^{4} \mathrm{~J}_{2,2},=-2 \mathrm{~Hz}, 2-\mathrm{H}\right), 11.42(\mathrm{~s}, \mathrm{COOH})$;

${ }^{13} \mathrm{C}-\mathrm{NMR}\left(50 \mathrm{MHz}, \mathrm{CDCl}_{3}\right): \delta 18.10\left(\mathrm{CH}^{\mathrm{CH}}{ }_{3}\right), 22.39\left(\mathrm{CH}_{2} \mathrm{CH}\left(\underline{\mathrm{CH}}_{3}\right)_{2}\right), 30.16\left(\mathrm{CH}_{2} \underline{\mathrm{CH}}\left(\mathrm{CH}_{3}\right)_{2}\right)$, $44.96\left(\mathrm{CHCH}_{3}\right), 45.05\left(\mathrm{CH}_{2} \mathrm{CH}(\mathrm{CH} 3)_{2}\right), 127.28$ (3-C,3'-C), 129.40 (2-C,2'-C), 136.97 (1-C), 140.86 (4-C), $180.84(\mathrm{CO})$.

\section{3. (2S)-2-(6-methoxy-2-naphtyl) propan-1-ol ((2S)-3)}

${ }^{1} \mathrm{H}-\mathrm{NMR}\left(200 \mathrm{MHz}, \mathrm{CDCl}_{3}\right): \delta 1.33\left(\mathrm{~d},{ }^{3} \mathrm{~J}_{\mathrm{CHCH}_{3}}=7 \mathrm{~Hz}, \mathrm{CHCH}_{3}\right), 1.50\left(\mathrm{~s}, \mathrm{CH}_{2} \mathrm{O} \underline{\mathrm{H}}\right), 3.06(\mathrm{~m}$, $\left.{ }^{3} \mathrm{~J}_{\mathrm{CHCH}_{3}}=7 \mathrm{~Hz},{ }^{3} \mathrm{~J}_{\mathrm{CH}_{2} \mathrm{CH}}=7 \mathrm{~Hz}, \underline{\mathrm{CHCH}}_{3}\right), 3.74\left(\mathrm{~d},{ }^{3} \mathrm{~J}_{\mathrm{CH}_{2} \mathrm{CH}}=7 \mathrm{~Hz}, \underline{\mathrm{CH}}_{2} \mathrm{OH}\right), 3.90\left(\mathrm{~s}, \mathrm{OCH}_{3}\right), 7.10(\mathrm{~d}$, $\left.{ }^{4} \mathrm{~J}_{5,7}=-2 \mathrm{~Hz}, 5-\mathrm{H}\right), 7.13\left(\mathrm{dd},{ }^{3} \mathrm{~J}_{7,8}=8 \mathrm{~Hz},{ }^{4} \mathrm{~J}_{5,7}=-2 \mathrm{~Hz}, 7-\mathrm{H}\right), 7.32\left(\mathrm{dd},{ }^{3} \mathrm{~J}_{3,4}=8 \mathrm{~Hz},{ }^{4} \mathrm{~J}_{1,3}=-2 \mathrm{~Hz}\right.$, $3-\mathrm{H}), 7.59\left(\mathrm{~d},{ }^{4} \mathrm{~J}_{1,3}=-2 \mathrm{~Hz}, 1-\mathrm{H}\right), 7.69\left(\mathrm{~d},{ }^{3} \mathrm{~J}_{3,4}=8 \mathrm{~Hz}, 4-\mathrm{H}\right), 7.70\left(\mathrm{~d},{ }^{3} \mathrm{~J}_{7,8}=8 \mathrm{~Hz}, 8-\mathrm{H}\right)$;

${ }^{13} \mathrm{C}-\mathrm{NMR}\left(50 \mathrm{MHz}, \mathrm{CDCl}_{3}\right): \delta 17.66\left(\mathrm{CHC}_{3}\right), 42.39\left(\underline{\mathrm{CHCH}}_{3}\right), 55.32\left(\mathrm{OCH}_{3}\right), 68.63\left(\mathrm{CH}_{2} \mathrm{OH}\right)$, 105.65 (5-C), 118.91 (7-C), 125.90 (1-C), 126.30 (3-C), 127.22 (4-C), 129.08 (8a-C), 129.12 (8-C), 133.57 (4a-C), 138.74 (2-C), 157.46 (6-C). 


\section{4. (2S)-2-(4-isobutylphenyl) propan-1-ol ((2S)-4)}

${ }^{1} \mathrm{H}-\mathrm{NMR}\left(300 \mathrm{MHz}, \mathrm{CDCl}_{3}\right): \delta 0.89\left(\mathrm{~d},{ }^{3} \mathrm{~J}_{\mathrm{CH}_{(}\left(\mathrm{CH}_{3}\right)_{2}}=7 \mathrm{~Hz}, \mathrm{CH}_{2} \mathrm{CH}\left(\mathrm{C}_{3}\right)_{2}\right), 1.25\left(\mathrm{~d},{ }^{3} \mathrm{~J}_{\mathrm{CHCH}_{3}}=7 \mathrm{~Hz}\right.$, $\left.\mathrm{CHC} \underline{H}_{3}\right), 1.75\left(\mathrm{~s}, \mathrm{CH}_{2} \mathrm{O} \underline{\mathrm{H}}\right), 2.44\left(\mathrm{~d},{ }^{3} \mathrm{~J}_{\mathrm{CHCH}_{2}}=7 \mathrm{~Hz}, \underline{\mathrm{CH}}_{2} \mathrm{CH}\left(\mathrm{CH}_{3}\right)_{2}\right), 2.90\left(\mathrm{~m},{ }^{3} \mathrm{~J}_{\mathrm{CH}_{(}\left(\mathrm{CH}_{3}\right)_{2}}={ }^{3} \mathrm{~J}_{\mathrm{CHCH}_{2}}=\right.$ $\left.7 \mathrm{~Hz}, \mathrm{CH}_{2} \mathrm{C} \underline{\mathrm{H}}\left(\mathrm{CH}_{3}\right)_{2}\right), 3.65\left(\mathrm{q},{ }^{3} \mathrm{~J}_{\mathrm{CHCH}_{3}}=7 \mathrm{~Hz}, \mathrm{CHCH}_{3}\right), 7.09\left(\mathrm{dd},{ }^{3} \mathrm{~J}_{3,2}=6 \mathrm{~Hz},{ }^{4} \mathrm{~J}_{3,3},=-2 \mathrm{~Hz}, 3-\mathrm{H}\right)$, $7.13\left(\mathrm{dd},{ }^{3} \mathrm{~J}_{3,2}=6 \mathrm{~Hz},{ }^{4} \mathrm{~J}_{2,2},=-2 \mathrm{~Hz}, 2-\mathrm{H}\right)$;

${ }^{13} \mathrm{C}-\mathrm{NMR}\left(75 \mathrm{MHz}, \mathrm{CDCl}_{3}\right): \delta 17.58\left(\mathrm{CHCH}_{3}\right), 22.38\left(\mathrm{CH}_{2} \mathrm{CH}(\underline{\mathrm{CH}})_{2}\right), 30.16\left(\mathrm{CH}_{2} \underline{\mathrm{CH}}\left(\mathrm{CH}_{3}\right)_{2}\right)$,

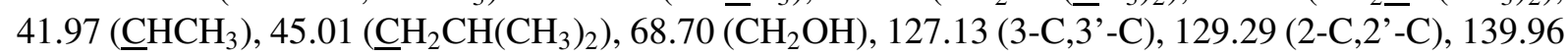
(1-C), 140.79 (4-C).

\section{5. (2S)-2-(6-methoxy-2-naphtyl)propyl (2S)-2-(6-methoxy-2-naphtyl) propanoate ((2'S,2S)-5)}

${ }^{1} \mathrm{H}-\mathrm{NMR}\left(200 \mathrm{MHz}, \mathrm{CDCl}_{3}\right): \delta 1.26\left(\mathrm{~d},{ }^{3} \mathrm{~J}_{\mathrm{CHCH}_{3}}=7 \mathrm{~Hz}, \mathrm{CH}_{2} \mathrm{CHCH}_{3}\right), 1.45\left(\mathrm{~d},{ }^{3} \mathrm{~J}_{\mathrm{CHCH}_{3}}=7 \mathrm{~Hz}\right.$, $\left.\mathrm{CHC}_{3}\right), 3.11\left(\mathrm{~m},{ }^{3} \mathrm{~J}_{\mathrm{CHCH}_{3}}=7 \mathrm{~Hz},{ }^{3} \mathrm{~J}_{\mathrm{CH}_{2}-\mathrm{Ha}, \mathrm{CH}}=7 \mathrm{~Hz},{ }^{3} \mathrm{~J}_{\mathrm{CH}_{2}-\mathrm{Hb}, \mathrm{CH}}=7 \mathrm{~Hz}, \mathrm{CH}_{2} \mathrm{CHCH}_{3}\right), 3.68(\mathrm{q}$, $\left.{ }^{3} \mathrm{~J}_{\mathrm{CHCH}_{3}}=7 \mathrm{~Hz}, \mathrm{CHCH}_{3}\right), 3.91\left(\mathrm{~s}, \mathrm{OCH}_{3}\right), 3.92\left(\mathrm{~s}, \mathrm{OCH}_{3}\right), 4.12\left(\mathrm{dd},{ }^{3} \mathrm{~J}_{\mathrm{CH}_{2}-\mathrm{Ha}, \mathrm{CH}}=7 \mathrm{~Hz},{ }^{2} \mathrm{~J}=-13 \mathrm{~Hz}\right.$, $\left.\mathrm{CH}_{2}-\mathrm{Ha}\right), 4.18\left(\mathrm{dd},{ }^{3} \mathrm{~J}_{\mathrm{CH}_{2}-\mathrm{Hb}, \mathrm{CH}}=7 \mathrm{~Hz},{ }^{2} \mathrm{~J}=-13 \mathrm{~Hz}, \mathrm{CH}_{2}-\mathrm{Hb}\right), 7.05-7.7$ (12 unresolved aromatic protons);

${ }^{13} \mathrm{C}-\mathrm{NMR}\left(50 \mathrm{MHz}, \mathrm{CDCl}_{3}\right): \delta 17.96\left(\mathrm{CH}_{2} \mathrm{CHCH}_{3}\right), 18.30\left(\mathrm{CHCH}_{3}\right), 38.82\left(\mathrm{CH}_{2} \mathrm{CHCH}_{3}\right), 45.51$ $\left(\underline{\mathrm{CHCH}}{ }_{3}\right), 55.28\left(\mathrm{OCH}_{3}\right.$ and $\left.\mathrm{OCH}_{3}{ }^{\prime}\right), 69.57\left(\underline{\mathrm{CH}}_{2} \mathrm{CHCH}_{3}\right), 105.52$ (5'-C), 105.57 (5-C), 118.66 (7'-C), 118.84 (7-C), 125.53, 125.93, 126.18, 126.23, 126.24, 126.80, 127.01 (1-C, 1'-C, 3-C, 3'-C, 4-C, 4'-C, 8'-C), 128.89 (8a-C), 129.09 (8a'-C), 129.27 (8-C), 133.38 (4a'-C), 133.63 (4a-C), 135.61 (2-C), 138.25 (2'-C), 157.34 (6'-C), 157.57 (6-C), 174.50 (CO).

\section{6. (2R)-2-(6-methoxy-2-naphtyl)propyl (2S)-2-(6-methoxy-2-naphtyl) propanoate ((2'R,2S)-5)}

${ }^{1} \mathrm{H}-\mathrm{NMR}\left(200 \mathrm{MHz}, \mathrm{CDCl}_{3}\right): \delta 1.26\left(\mathrm{~d},{ }^{3} \mathrm{~J}_{\mathrm{CHCH}_{3}}=7 \mathrm{~Hz}, \mathrm{CH}_{2} \mathrm{CHCH}_{3}\right), 1.51\left(\mathrm{~d},{ }^{3} \mathrm{~J}_{\mathrm{CHCH}_{3}}=7 \mathrm{~Hz}\right.$, $\left.\mathrm{CHC}_{3}\right), 3.17\left(\mathrm{~m},{ }^{3} \mathrm{~J}_{\mathrm{CHCH}_{3}}=7 \mathrm{~Hz},{ }^{3} \mathrm{~J}_{\mathrm{CH}_{2}-\mathrm{Ha}, \mathrm{CH}}=7 \mathrm{~Hz},{ }^{3} \mathrm{~J}_{\mathrm{CH}_{2}-\mathrm{Hb}, \mathrm{CH}}=7 \mathrm{~Hz}, \mathrm{CH}_{2} \mathrm{CHCH}_{3}\right), 3.79(\mathrm{q}$, $\left.{ }^{3} \mathrm{~J}_{\mathrm{CHCH}_{3}}=7 \mathrm{~Hz}, \mathrm{CHCH}_{3}\right), 3.91\left(\mathrm{~s}, \mathrm{OCH}_{3}\right), 3.92\left(\mathrm{~s}, \mathrm{OCH}_{3}{ }^{\prime}\right), 4.15\left(\mathrm{dd},{ }^{3} \mathrm{~J}_{\mathrm{CH}_{2}-\mathrm{Ha}, \mathrm{CH}}=7 \mathrm{~Hz},{ }^{2} \mathrm{~J}=-13 \mathrm{~Hz}\right.$, $\mathrm{CH}_{2}-\mathrm{Ha}$ ), $4.33\left(\mathrm{dd},{ }^{3} \mathrm{~J}_{\mathrm{CH}_{2}-\mathrm{Hb}, \mathrm{CH}}=7 \mathrm{~Hz},{ }^{2} \mathrm{~J}=-13 \mathrm{~Hz}, \mathrm{CH}_{2}-\mathrm{Hb}\right.$ ), 7.05-7.7 (12 unresolved aromatic protons).

\section{7. (2S)-2-(6-methoxy-2-naphtyl)propyl (2R)-2-(6-methoxy-2-naphtyl) propanoate ((2'S,2R)-5)}

${ }^{1} \mathrm{H}-\mathrm{NMR}\left(200 \mathrm{MHz}, \mathrm{CDCl}_{3}\right): \delta 1.26\left(\mathrm{~d},{ }^{3} \mathrm{~J}_{\mathrm{CHCH}_{3}}=7 \mathrm{~Hz}, \mathrm{CH}_{2} \mathrm{CHCH}_{3}\right), 1.50\left(\mathrm{~d},{ }^{3} \mathrm{~J}_{\mathrm{CHCH}_{3}}=7 \mathrm{~Hz}\right.$, $\left.\mathrm{CHCH}_{3}\right), 3.16\left(\mathrm{~m},{ }^{3} \mathrm{~J}_{\mathrm{CHCH}_{3}}=7 \mathrm{~Hz},{ }^{3} \mathrm{~J}_{\mathrm{CH}_{2}-\mathrm{Ha}, \mathrm{CH}}=7 \mathrm{~Hz},{ }^{3} \mathrm{~J}_{\mathrm{CH}_{2}-\mathrm{Hb}, \mathrm{CH}}=7 \mathrm{~Hz}, \mathrm{CH}_{2} \mathrm{CHCH}_{3}\right), 3.79$ (q, $\left.{ }^{3} \mathrm{~J}_{\mathrm{CHCH}_{3}}=7 \mathrm{~Hz}, \mathrm{CHCH}_{3}\right), 3.91\left(\mathrm{~s}, \mathrm{OCH}_{3}\right), 3.92\left(\mathrm{~s}, \mathrm{OCH}_{3}{ }^{\prime}\right), 4.16\left(\mathrm{dd},{ }^{3} \mathrm{~J}_{\mathrm{CH}_{2}-\mathrm{Ha}, \mathrm{CH}}=7 \mathrm{~Hz},{ }^{2} \mathrm{~J}=-13 \mathrm{~Hz}\right.$, $\left.\mathrm{CH}_{2}-\mathrm{Ha}\right), 4.34\left(\mathrm{dd},{ }^{3} \mathrm{~J}_{\mathrm{CH}_{2}-\mathrm{Hb}, \mathrm{CH}}=7 \mathrm{~Hz},{ }^{2} \mathrm{~J}=-13 \mathrm{~Hz}, \mathrm{CH}_{2}-\mathrm{Hb}\right), 7.05-7.7$ (12 unresolved aromatic protons).

\section{8. (2R)-2-(6-methoxy-2-naphtyl)propyl (2R)-2-(6-methoxy-2-naphtyl) propanoate ((2'R,2R)-5)}

${ }^{1} \mathrm{H}-\mathrm{NMR}\left(200 \mathrm{MHz}, \mathrm{CDCl}_{3}\right): \delta 1.26\left(\mathrm{~d},{ }^{3} \mathrm{~J}_{\mathrm{CHCH}_{3}}=7 \mathrm{~Hz}, \mathrm{CH}_{2} \mathrm{CHC}_{3}\right), 1.50\left(\mathrm{~d},{ }^{3} \mathrm{~J}_{\mathrm{CHCH}_{3}}=7 \mathrm{~Hz}\right.$, $\left.\mathrm{CHCH}_{3}\right), 3.15\left(\mathrm{~m},{ }^{3} \mathrm{~J}_{\mathrm{CHCH}_{3}}=7 \mathrm{~Hz},{ }^{3} \mathrm{~J}_{\mathrm{CH}_{2}-\mathrm{Ha}, \mathrm{CH}}=7 \mathrm{~Hz},{ }^{3} \mathrm{~J}_{\mathrm{CH}_{2}-\mathrm{Hb}, \mathrm{CH}}=7 \mathrm{~Hz}, \mathrm{CH}_{2} \mathrm{CHCH}_{3}\right), 3.78(\mathrm{q}$, $\left.{ }^{3} \mathrm{~J}_{\mathrm{CHCH}_{3}}=7 \mathrm{~Hz}, \underline{\mathrm{CHCH}}_{3}\right), 3.91\left(\mathrm{~s}, \mathrm{OCH}_{3}\right), 3.92\left(\mathrm{~s}, \mathrm{OCH}_{3}\right), 4.20\left(\mathrm{dd},{ }^{3} \mathrm{~J}_{\mathrm{CH}_{2}-\mathrm{Ha}, \mathrm{CH}}=7 \mathrm{~Hz},{ }^{2} \mathrm{~J}=-13 \mathrm{~Hz}\right.$, $\mathrm{CH}_{2}-\mathrm{Ha}$ ), $4.27\left(\mathrm{dd},{ }^{3} \mathrm{~J}_{\mathrm{CH}_{2}-\mathrm{Hb}, \mathrm{CH}}=7 \mathrm{~Hz},{ }^{2} \mathrm{~J}=-13 \mathrm{~Hz}, \mathrm{CH}_{2}-\mathrm{Hb}\right), 7.05-7.7$ (12 unresolved aromatic protons). 
${ }^{1} \mathrm{H}-\mathrm{NMR}\left(300 \mathrm{MHz}, \mathrm{CDCl}_{3}\right): \delta 0.85\left(\mathrm{~d},{ }^{3} \mathrm{~J}_{\mathrm{CH}_{(}\left(\mathrm{CH}_{3}\right)_{2}}=7 \mathrm{~Hz}, \mathrm{CH}_{2} \mathrm{CH}\left(\mathrm{C}_{3}\right)_{2}\right), 1.14\left(\mathrm{~d},{ }^{3} \mathrm{~J}_{\mathrm{CHCH}_{3}}=\right.$ $\left.7 \mathrm{~Hz}, \mathrm{OCH}_{2} \mathrm{CHC}_{3}\right), 1.50\left(\mathrm{~d},{ }^{3} \mathrm{~J}_{\mathrm{CHCH}_{3}}=7 \mathrm{~Hz}, \mathrm{CHCH}_{3}\right) ; 1.77\left(\mathrm{~m},{ }^{3} \mathrm{~J}_{\mathrm{CH}_{(}\left(\mathrm{CH}_{3}\right)_{2}}={ }^{3} \mathrm{~J}_{\mathrm{CH}_{2} \mathrm{CH}}=7 \mathrm{~Hz}\right.$, $\left.\mathrm{CH}_{2} \mathrm{C} \underline{\mathrm{H}}\left(\mathrm{CH}_{3}\right)_{2}\right), 2.36\left(\mathrm{~d},{ }^{3} \mathrm{~J}_{\mathrm{CH}_{2} \mathrm{CH}}=7 \mathrm{~Hz}, \mathrm{CH}_{2} \mathrm{CH}\left(\mathrm{CH}_{3}\right)_{2}\right), 2.94\left(\mathrm{~m},{ }^{3} \mathrm{~J}_{\mathrm{CHCH}_{3}}={ }^{3} \mathrm{~J}_{\mathrm{OCH}_{2} \mathrm{CH}}=7 \mathrm{~Hz}\right.$, $\left.\mathrm{OCH}_{2} \underline{\mathrm{C}}_{\mathrm{CH}}\right), 3.76\left(\mathrm{q},{ }^{3} \mathrm{~J}_{\mathrm{CHCH}_{3}}=7 \mathrm{~Hz}, \mathrm{CHCH}_{3}\right), 3.81\left(\mathrm{~s}, \mathrm{OCH}_{3}\right), 4.12\left(\mathrm{~d},{ }^{3} \mathrm{~J}_{\mathrm{OCH}_{2} \mathrm{CH}}=7 \mathrm{~Hz}\right.$, $\left.\mathrm{OCH}_{2} \mathrm{CHCH}_{3}\right), 6.8-7.0\left(\mathrm{~m}\right.$, unresolved $2{ }^{\prime}-\mathrm{H}$ and $\left.3^{\prime}-\mathrm{H}\right), 7.06\left(\mathrm{~d},{ }^{4} \mathrm{~J}_{\mathrm{H} 5,7}=-2 \mathrm{~Hz}, 5-\mathrm{H}\right), 7.11(\mathrm{dd}$, $\left.{ }^{4} \mathrm{~J}_{5,7}=-2 \mathrm{~Hz},{ }^{3} \mathrm{~J}_{7,8}=8 \mathrm{~Hz}, 7-\mathrm{H}\right), 7.32\left(\mathrm{dd},{ }^{4} \mathrm{~J}_{1,3}=-2 \mathrm{~Hz},{ }^{3} \mathrm{~J}_{3,4}=8 \mathrm{~Hz} 3-\mathrm{H}\right), 7.58\left(\mathrm{~d},{ }^{4} \mathrm{~J}_{1,3}=-2 \mathrm{~Hz}\right.$, 1-H); 7.63-7.64 (d, ${ }^{3} \mathrm{~J}_{3,4}={ }^{3} \mathrm{~J}_{7,8}=8 \mathrm{~Hz}, 4-\mathrm{H}$ and 8-H overlap);

${ }^{13} \mathrm{C}-\mathrm{NMR}\left(75 \mathrm{MHz}, \mathrm{CDCl}_{3}\right): \delta 17.66\left(\mathrm{OCH}_{2} \mathrm{CHCH}_{3}\right), 18.14\left(\mathrm{CHCH}_{3}\right), 22.23\left(\mathrm{CH}_{2} \mathrm{CH}\left(\mathrm{CH}_{3}\right)_{2}\right), 29.97$ $\left(\mathrm{CH}_{2} \underline{\mathrm{CH}}\left(\mathrm{CH}_{3}\right)_{2}\right), 38.36\left(\mathrm{OCH}_{2} \underline{\mathrm{CHCH}} 3\right), 44.84\left(\underline{\mathrm{C}} \mathrm{HCH}_{3}\right), 45.34\left(\underline{\mathrm{CH}}_{2} \mathrm{CH}\left(\mathrm{CH}_{3}\right)_{2}\right), 54.96\left(\mathrm{OCH}_{3}\right), 69.56$ $\left(\mathrm{OCH}_{2} \mathrm{CHCH}_{3}\right), 105.40$ (5-C), 118.75 (7-C), 125.89 (1-C), 126.12 (3-C), 126.78 (3'-C), 126.91 (4-C), 128.81 (8a-C), 128.86 (2'-C), 129.13 (8-C), 133.56 (4a-C), 135.51 (1'-C), 139.57 (2-C), 140.07 (4'-C), $157.46(6-\mathrm{C}), 174.26(\mathrm{CO})$.

5.10. (2S)-2-(6-methoxy-2-naphtyl) propyl (2S)-2-(4-isobutylphenyl) propanoate ((2'S,2S)-7)

${ }^{1} \mathrm{H}-\mathrm{NMR}\left(400 \mathrm{MHz}, \mathrm{CDCl}_{3}\right): \delta 0.90\left(\mathrm{~d},{ }^{3} \mathrm{~J}_{\mathrm{CH}_{(}\left(\mathrm{CH}_{3}\right)_{2}}=7 \mathrm{~Hz}, \mathrm{CH}_{2} \mathrm{CH}\left(\mathrm{CH}_{3}\right)_{2}\right), 1.23\left(\mathrm{~d},{ }^{3} \mathrm{~J}_{\mathrm{CHCH}_{3}}=\right.$ $\left.7 \mathrm{~Hz}, \mathrm{OCH}_{2} \mathrm{CHC}_{3}\right), 1.40\left(\mathrm{~d},{ }^{3} \mathrm{~J}_{\mathrm{CHCH}_{3}}=7 \mathrm{~Hz}, \mathrm{CHCH}_{3}\right) ; 1.78\left(\mathrm{~m},{ }^{3} \mathrm{~J}_{\mathrm{CH}_{(}\left(\mathrm{CH}_{3}\right)_{2}}={ }^{3} \mathrm{~J}_{\mathrm{CH}_{2} \mathrm{CH}}=7 \mathrm{~Hz}\right.$, $\left.\mathrm{CH}_{2} \mathrm{C} \underline{\mathrm{H}}\left(\mathrm{CH}_{3}\right)_{2}\right), 2.38\left(\mathrm{~d},{ }^{3} \mathrm{~J}_{\mathrm{CH}_{2} \mathrm{CH}}=7 \mathrm{~Hz}, \mathrm{CH}_{2} \mathrm{CH}\left(\mathrm{CH}_{3}\right)_{2}\right), 3.14\left(\mathrm{~m},{ }^{3} \mathrm{~J}_{\mathrm{CHCH}_{3}}={ }^{3} \mathrm{~J}_{\mathrm{OCH}_{2} \mathrm{CH}}=7 \mathrm{~Hz}\right.$, $\left.\mathrm{OCH}_{2} \mathrm{CHCH}_{3}\right), 3.61\left(\mathrm{q},{ }^{3} \mathrm{~J}_{\mathrm{CHCH}_{3}}=7 \mathrm{~Hz}, \underline{\mathrm{CHCH}}_{3}\right), 3.90\left(\mathrm{~s}, \mathrm{OCH}_{3}\right), 4.18\left(\mathrm{~d},{ }^{3} \mathrm{~J}_{\mathrm{OCH}_{2} \mathrm{CH}}=7 \mathrm{~Hz}\right.$, $\mathrm{OC}_{2} \mathrm{CHCH}_{3}$ ), 6.9-7.7 (10 unresolved aromatic protons).

\subsection{Phenyl-acetic acid benzyl ester (8)}

${ }^{1} \mathrm{H}-\mathrm{NMR}\left(200 \mathrm{MHz}, \mathrm{CDCl}_{3}\right): 3.63\left(\mathrm{~s}, \mathrm{CH}_{2} \mathrm{COOC}_{2}\right), 5.10$ (s, $\left.\underline{\mathrm{CH}}_{2} \mathrm{COOCH}_{2}\right), 7.2-7.4$ (m, 10 aromatic protons);

${ }^{13} \mathrm{C}-\mathrm{NMR}\left(50 \mathrm{MHz}, \mathrm{CDCl}_{3}\right): 41.13\left(\mathrm{CH}_{2} \mathrm{COOCH} 2\right), 66.39\left(\mathrm{CH} 2 \mathrm{COOCH}_{2}\right), 126.94$ (4'-C), 127.93 (3'-C, 5'-C), 128.02 (4-C), 128.34 (3-C, 5-C), 128.38 (2'-C, 6'-C), 129.12 (2-C, 6-C), 133.74 (1-C), $135.70\left(1^{\prime}-\mathrm{C}\right), 171.21(\mathrm{CO})$.

\subsection{Phenyl-acetic acid phenethyl ester (9)}

${ }^{1} \mathrm{H}-\mathrm{NMR}\left(200 \mathrm{MHz}, \mathrm{CDCl}_{3}\right): 2.84\left(\mathrm{t},{ }^{3} \mathrm{~J}_{\mathrm{CH}_{2} \mathrm{CH}_{2}}=7 \mathrm{~Hz}, \mathrm{C}_{2} \mathrm{CH}_{2} \mathrm{O}\right), 3.52\left(\mathrm{~s}, \mathrm{C}_{2} \mathrm{CO}\right), 4.23(\mathrm{t}$, $\left.{ }^{3} \mathrm{~J}_{\mathrm{CH}_{2} \mathrm{CH}_{2}}=7 \mathrm{~Hz}, \mathrm{CH}_{2} \mathrm{CH}_{2} \mathrm{O}\right), 7.0-7.4(\mathrm{~m}), 10$ aromatic protons);

${ }^{13} \mathrm{C}-\mathrm{NMR}\left(50 \mathrm{MHz}, \mathrm{CDCl}_{3}\right): 34.84\left(\mathrm{CH}_{2} \mathrm{COOCH}_{2} \mathrm{CH}_{2}\right), 41.19\left(\mathrm{CH}_{2} \mathrm{COOCH}_{2} \mathrm{CH}_{2}\right), 65.08\left(\mathrm{CH}_{2}-\right.$ $\mathrm{COOCH}_{2} \mathrm{CH}_{2}$ ), 126.32 (4'-C), 126.84 (4-C), 128.27 (2'-C, 6'-C), 128.34 (3'-C, 5'-C), 128.72 (3-C, 5-C), 129.09 (2-C, 6-C), 133.85 (1-C), 137.57 (1'-C), 171.15 (CO).

\subsection{3. ( \pm )2-methyl 3-butenyl (2S)-2-(6-méthoxy-2-naphtyl) propanoate $(( \pm 2 S)-12)$ (mixture of diastereoisomers)}

${ }^{1} \mathrm{H}-\mathrm{NMR}\left(200 \mathrm{MHz}, \mathrm{CDCl}_{3}\right): \delta 0.91\left(\mathrm{~d},{ }^{3} \mathrm{~J}_{\mathrm{CHCH}_{3}}=7 \mathrm{~Hz}, \mathrm{OCH}_{2} \mathrm{CHCH}_{3}\right), 1.56\left(\mathrm{~d},{ }^{3} \mathrm{~J}_{\mathrm{CHCH}_{3}}=7 \mathrm{~Hz}\right.$, $\left.\mathrm{CHC}_{3}\right), 2.43\left(\mathrm{~m},{ }^{3} \mathrm{~J}_{\mathrm{CHCH}_{3}}=7 \mathrm{~Hz},{ }^{3} \mathrm{~J}_{\mathrm{CHCH}_{2}}=7 \mathrm{~Hz},{ }^{3} \mathrm{~J}_{\mathrm{CHCH}}=7 \mathrm{~Hz},{ }^{4} \mathrm{~J}_{2}, 4^{\prime}=-1 \mathrm{~Hz},{ }^{4} \mathrm{~J}_{2},{ }^{\prime},{ }^{\prime}=-2 \mathrm{~Hz}\right.$, $\left.\mathrm{OCH}_{2} \mathrm{CHCH}_{3}\right), 3.83\left(\mathrm{q},{ }^{3} \mathrm{~J}_{\mathrm{CHCH}_{3}}=7 \mathrm{~Hz}, \mathrm{C}^{\mathrm{HCH}}{ }_{3}\right), 3.84\left(\mathrm{~s}, \mathrm{OCH}_{3}\right), 3.96\left(\mathrm{~d}, \mathrm{OC}_{2} \mathrm{CHCH}_{3}\right), 4.95$ (ddd, $\left.{ }^{3} \mathrm{~J}_{4 a^{\prime}, 3^{\prime}}=10 \mathrm{~Hz},{ }^{2} \mathbf{J}=-1 \mathrm{~Hz},{ }^{4} \mathbf{J}_{2^{\prime}, 4 a^{\prime}}=-1 \mathrm{~Hz}, 4 \mathrm{a}^{\prime}-\mathrm{H}\right), 5.05\left(\mathrm{ddd},{ }^{3} \mathrm{~J}_{4 b^{\prime}, 3^{\prime}}=17 \mathrm{~Hz},{ }^{2} \mathbf{J}=-1 \mathrm{~Hz}\right.$, 
$\left.{ }^{4} \mathbf{J}_{2^{\prime}, 4 b^{\prime}}=-1 \mathrm{~Hz}, 4 \mathrm{~b}^{\prime}-\mathrm{H}\right), 5.73\left(\mathrm{ddd},{ }^{3} \mathbf{J}_{2^{\prime}, 3^{\prime}}=7 \mathrm{~Hz},{ }^{3} \mathrm{~J}_{4 a^{\prime}, 3^{\prime}}=10 \mathrm{~Hz},{ }^{3} \mathrm{~J}_{4 b^{\prime}, 3^{\prime}}=17 \mathrm{~Hz}, 3{ }^{\prime}-\mathrm{H}\right), 7.09(\mathrm{~d}$, $\left.{ }^{4} \mathbf{J}_{5,7}=-2 \mathrm{~Hz}, 5-\mathrm{H}\right), 7.12\left(\mathrm{dd},{ }^{3} \mathbf{J}_{7.8}=8 \mathrm{~Hz},{ }^{4} \mathbf{J}_{5,7}=-2 \mathrm{~Hz}, 7-\mathrm{H}\right), 7.39\left(\mathrm{dd},{ }^{3} \mathbf{J}_{3,4}=8 \mathrm{~Hz},{ }^{4} \mathbf{J}_{1,3}=-2 \mathrm{~Hz}\right.$, 3-H), $7.67\left(\mathrm{~d},{ }^{4} \mathrm{~J}_{1,3}=-2 \mathrm{~Hz}, 1-\mathrm{H}\right), 7.68\left(\mathrm{~d},{ }^{3} \mathrm{~J}_{3,4}=8 \mathrm{~Hz}, 4-\mathrm{H}\right), 7.69\left(\mathrm{~d},{ }^{3} \mathrm{~J}_{7,8}=8 \mathrm{~Hz}, 8-\mathrm{H}\right)$;

${ }^{13} \mathrm{C}-\mathrm{NMR}\left(50 \mathrm{MHz}, \mathrm{CDCl}_{3}\right): \delta 16.12\left(\mathrm{OCH}_{2} \mathrm{CHCH}_{3}\right), 18.30\left(\mathrm{CHCH}_{3}\right), 36.84$ and 36.92, (2'-C), $45.39\left(\mathrm{CHCH}_{3}\right), 55.07\left(\mathrm{OCH}_{3}\right), 68.32\left(\mathrm{OCH}_{2} \mathrm{CHCH}_{3}\right), 105.46(5-\mathrm{C}), 114.78\left(\mathrm{CH}=\mathrm{CH}_{2}\right), 118.80$ (7-C), 125.86 (1-C), 126.22 )3-C), 126.92 (4-C), 128.81 (8a-C), 129.12 (8-C), 133.58 (4a-C), 135.57 (2-C), 139.71 and $139.74\left(\underline{\mathrm{C}}=\mathrm{CH}_{2}\right), 157.50(6-\mathrm{C}), 174.36(\mathrm{CO})$.

\section{Acknowledgements}

We are grateful to Environment Canada, Patrimoine Canadien and to the Faculté d'études Supérieures et de la Recherche of the Université de Moncton, for help in financing this study. We would also like to thank S. Guignard for technical assistance.

\section{References}

[1] J.G. Lombardino, Nonsteroidal Anti-inflammatory Drugs (Chemistry and Pharmacology of Drugs: a Series of Monographs), Vol. 5, John Wiley \& Sons, New York, 1985, p. 82.

[2] J.R. Vane and R.M. Botting, Aspirin and Other Salicylates, Chapman \& Hall, London, 1992, pp. 3-16 and 20.

[3] M. Gonzales-de la Parra, C. Ramos-Mundo, M. Jimenez-Estrada, C. Ponce-de Leon, R. Castillo, V. Tejada, K.G. Cuevas and R. Enriquez, ATLA 26 (1998), 635.

[4] M. Gonzales-de la Parra, V. Tejada and M. Jimenez-Estrada, ATLA 27 (1999), 461.

[5] V.R. Shanbhag, A.M. Crider, R. Gokhale, A. Harpalani and R.M. Dick, J. Pharm. Sci. 81, (1992), 149.

[6] R.D. Knihinicki, K.M. Williams and R.O. Day, Bioch. Pharm. 38 (1989), 4389.

[7] R.D. Knihinicki, K.M. Williams and R.O. Day, Bioch. Pharm. 42 (1991), 1905.

[8] T.A. Baillie, W.J. Adams, D.G. Kaiser, L.S. Olanoff, G.W. Halstead, H. Harpootlian and G.J. van Giessen, J. Pharm. Exp. Ther. 249 (1989), 517.

[9] H.D. Langtry and A. Markham, Drugs 57 (1999), 967.

[10] E. Culotta and F.E. Koshland, Jr., Science 258 (1992), 1862.

[11] M.N. Davies, A.G. Roseth, C.B. Appleyard, W. McKnight, P. Del soldato, A. Calignano, G. Cirino and J.L. Wallace, Aliment. Pharmacol. Ther. 11 (1997), 69.

[12] J.L. Wallace, B.K. Reuter and G. Cirino, J. Gastroenterol. Hepatol. 9(Suppl. 1) (1994), s40.

[13] L. Perreux and A. Loupy, Tetrahedron 57 (2001), 9199.

[14] P. Lidström, J. Tierney, B. Wathey and J. Westman, Tetrahedron 57 (2001), 9225.

[15] C.K. Jankowski, G. LeClair, J.M.R. Bélanger, J.R.J. Paré, and M.-R. van Calsteren, Can. J. Chem. 79 (2001), 1906.

[16] J.R.J. Paré, J.M.R. Bélanger and M.M. Punt, U.S. Patent 6,061,926 (2000).

[17] I.T. Harrison, B. Lewis, P. Nelson, W. Rooks, A. Roszkowski, A. Tomolonis and J. Fried, J. Med. Chem. 13 (1970), 203.

[18] G.M. Whitesides and D.M. Lewis, J. Amer. Chem. Soc. 92 (1970), 6979.

[19] G.M. Whitesides and D.M. Lewis, J. Amer. Chem. Soc. 93 (1971), 5914

[20] G.J. Martin, N. Naulet, F. Lefevre and M.L. Martin, Org. Mag. Res. 4 (1972), 121.

[21] H. Garlach and B. Zagalak, Chem. Commun. (1973), 274.

[22] HyperChem 6.02, Hypercube Inc., Gainesville, FL, USA, 1999 (www.hyper.com). 


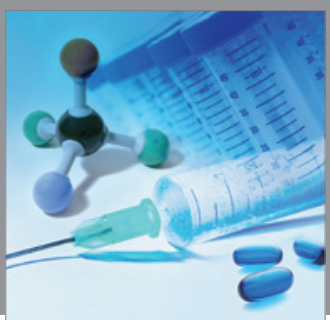

International Journal of

Medicinal Chemistry

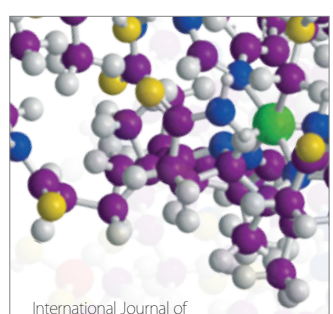

Carbohydrate Chemistry

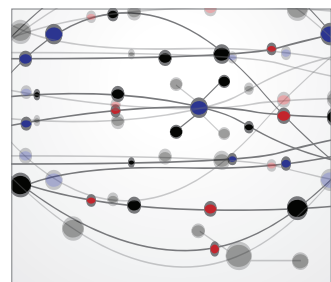

The Scientific World Journal
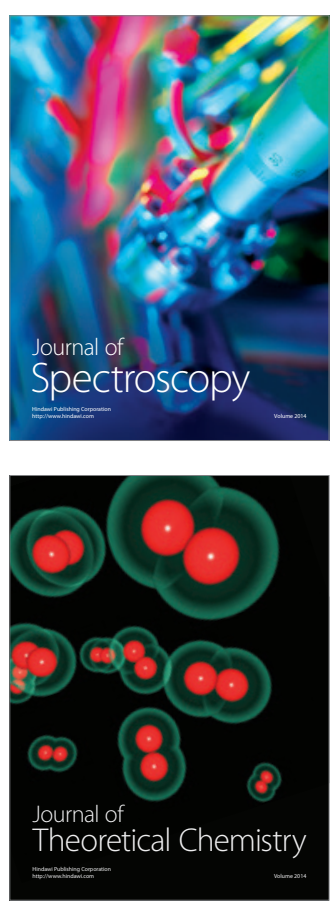
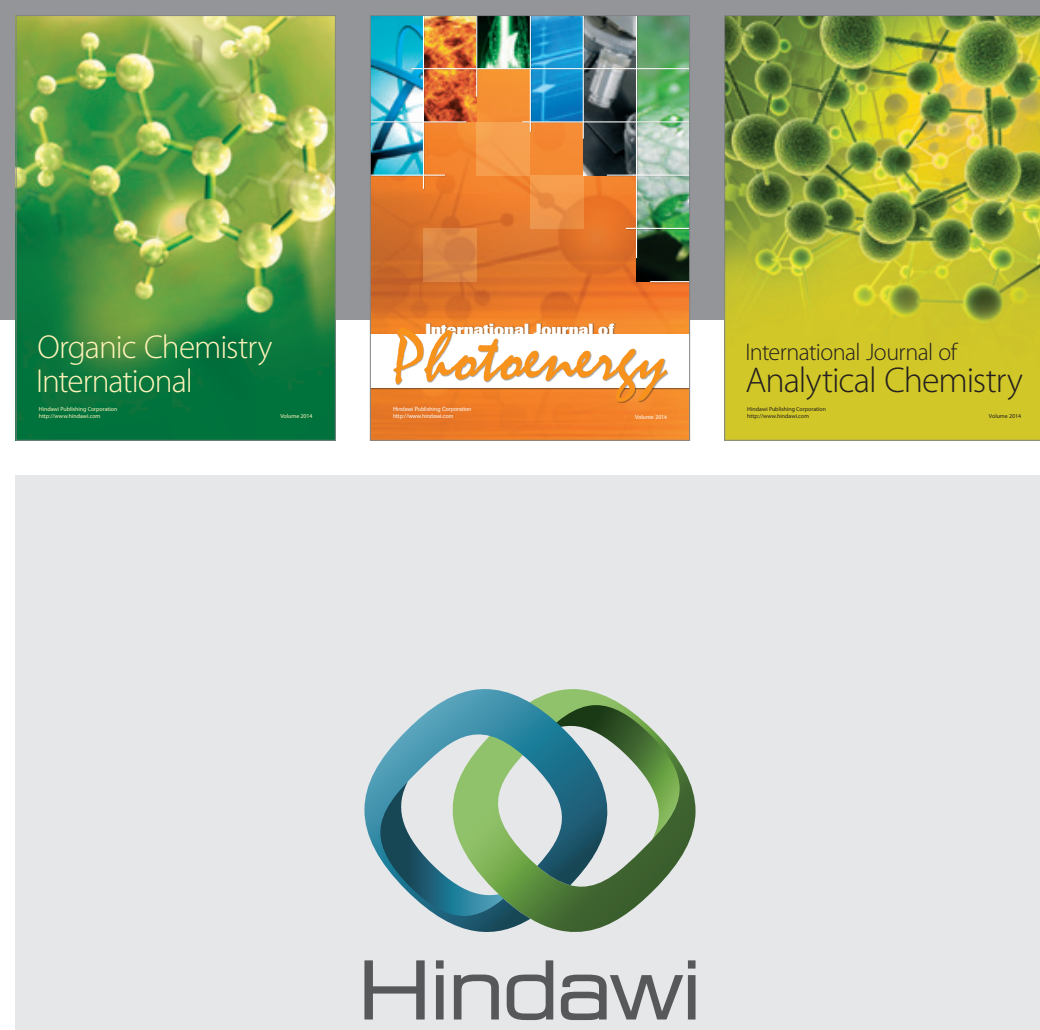

Submit your manuscripts at

http://www.hindawi.com
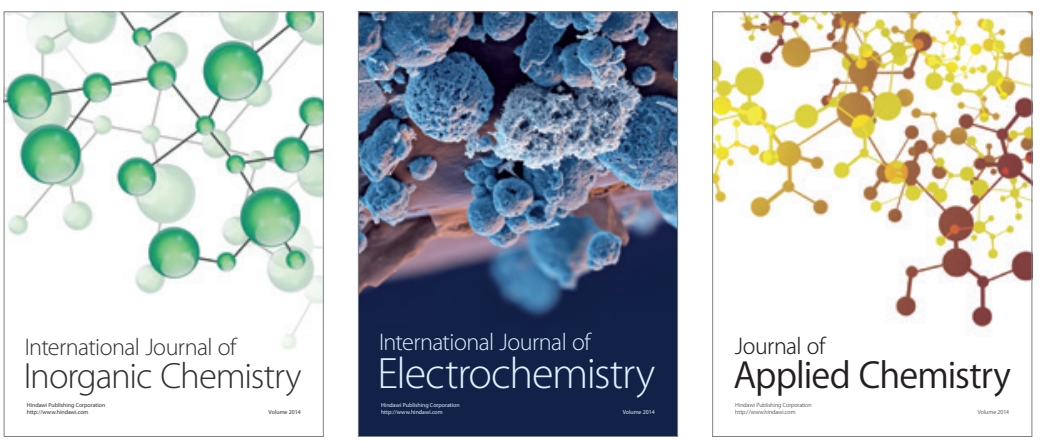

Journal of

Applied Chemistry
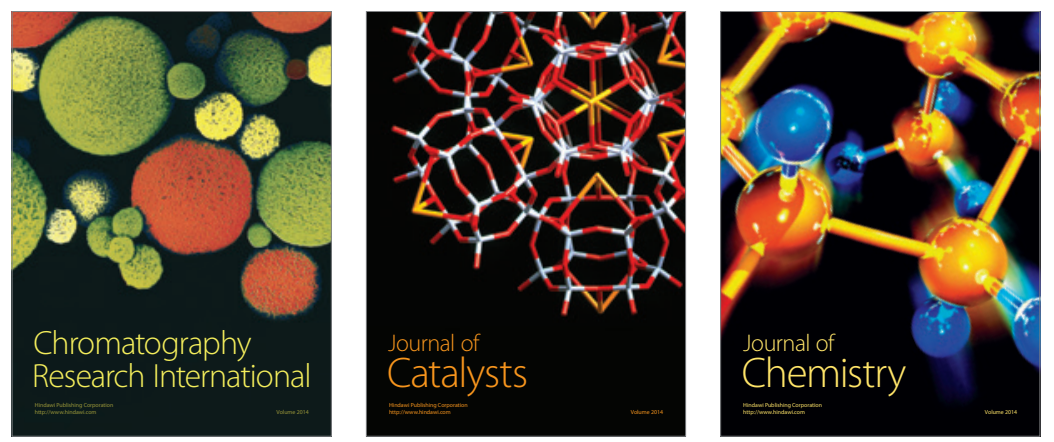
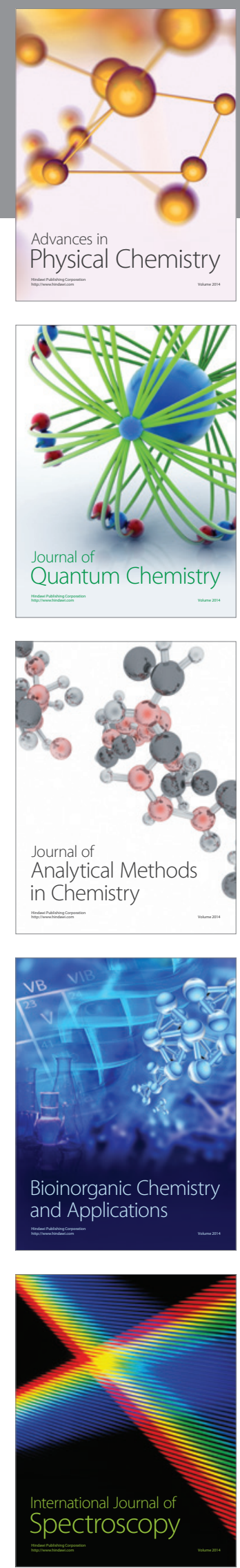